\title{
Acidification of pig slurry effects on ammonia and nitrous oxide emissions, nitrate leaching, and perennial ryegrass regrowth as estimated by ${ }^{15} \mathrm{~N}$-urea flux
}

\author{
Sang Hyun Park', Bok Rye Lee ${ }^{1,2}$, Kwang Hwa Jung ${ }^{3}$, and Tae Hwan Kim ${ }^{1, *}$
}

\begin{abstract}
* Corresponding Author: Tae Hwan Kim Tel: +82-62-530-2126, Fax: +82-62-530-2129,

E-mail: grass@@chonnam.ac.kr
\end{abstract}

' Department of Animal Science, Institute of Agricultural Science and Technology, College of Agriculture \& Life Science, Chonnam National University, Gwangju 61186, Korea

2 Biotechnology Research Institute, Chonnam National University, Gwangju 61186, Korea

${ }^{3}$ National Institute of Animal Science, Rural Development Administration, Wanju 55365, Korea

ORCID

Sang Hyun Park

https://orcid.org/0000-0002-8766-5077

Bok Rye Lee

https://orcid.org/0000-0002-1912-0390

Kwang Hwa Jung

https://orcid.org/0000-0001-9721-6323

Tae Hwan Kim

https://orcid.org/0000-0002-9202-1655

Submitted Jul 25, 2017; Revised Oct 2, 2017; Accepted Dec 2, 2017
Objective: The present study aimed to assess the nitrogen $(\mathrm{N})$ use efficiency of acidified pig slurry for regrowth yield and its environmental impacts on perennial ryegrass swards. Methods: The $\mathrm{pH}$ of digested pig slurry was adjusted to 5.0 or 7.0 by the addition of sulfuric acid and untreated as a control. The pig slurry urea of each treatment was labeled with ${ }^{15} \mathrm{~N}$ urea and applied at a rate of $200 \mathrm{~kg} \mathrm{~N} / \mathrm{ha}$ immediately after cutting. Soil and herbage samples were collected at 7, 14, and $56 \mathrm{~d}$ of regrowth. The flux of pig slurry- $\mathrm{N}$ to regrowth yield and soil $\mathrm{N}$ mineralization were analyzed, and $\mathrm{N}$ losses via $\mathrm{NH}_{3}, \mathrm{~N}_{2} \mathrm{O}$ emission and $\mathrm{NO}_{3}{ }^{-}$leaching were also estimated.

Results: The $\mathrm{pH}$ level of the applied slurry did not have a significant effect on herbage yield or $\mathrm{N}$ content of herbage at the end of regrowth, whereas the amount of $\mathrm{N}$ derived from pig slurry urea (NdfSU) was higher in both herbage and soils in $\mathrm{pH}$-controlled plots. The $\mathrm{NH}_{4}^{+}-\mathrm{N}$ content and the amount of $\mathrm{N}$ derived from slurry urea into soil $\mathrm{NH}_{4}^{+}$fraction (NdfSU- $\mathrm{NH}_{4}^{+}$) was significantly higher in in the $\mathrm{pH} 5$ plot, whereas $\mathrm{NO}_{3}{ }^{-}$and $\mathrm{NdfSU}-\mathrm{NO}_{3}{ }^{-}$were lower than in control plots over the entire regrowth period. Nitrification of $\mathrm{NH}_{4}{ }^{+} \mathrm{N}$ was delayed in soil amended with acidified slurry. Compared to non-pH-controlled pig slurry (i.e. control plots), application of acidified slurry reduced $\mathrm{NH}_{3}$ emissions by $78.1 \%, \mathrm{~N}_{2} \mathrm{O}$ emissions by $78.9 \%$ and $\mathrm{NO}_{3}^{-}$leaching by $17.81 \%$ over the course of the experiment.

Conclusion: Our results suggest that pig slurry acidification may represent an effective means of minimizing hazardous environmental impacts without depressing regrowth yield.

Keywords: Acidification; Gas Emission; Lolium perenne; Nitrate Leaching; Pig Slurry; Regrowth

\section{INTRODUCTION}

Manure emission from pig production accounts for $38.2 \%$ of the total quantity of manure issued from livestock production (46 million tons per year) in Korea. Since pig farms usually have little or no arable surface for forage production in Korea, utilization of pig slurry as an alternative organic fertilizer has become the most viable recycling option and composes more than $80 \%$ of all recycled animal manure [1]. However, mismanagement and application of nitrogen $(\mathrm{N})$ to pig slurry can increase the risk of environmental pollution via nutrient losses to air, soil, water, and the biosphere [2,3]. Animal manure is a major contributor of odorous gases (ammonia $\left[\mathrm{NH}_{3}\right]$ and hydrogen sulfide $\left[\mathrm{H}_{2} \mathrm{~S}\right]$ ) and greenhouse gases (GHGs; nitrous oxide $\left[\mathrm{N}_{2} \mathrm{O}\right]$, methane $\left[\mathrm{CH}_{4}\right]$, and carbon dioxide $\left.\left[\mathrm{CO}_{2}\right]\right)$ that strongly impact the environment. The largest pathway of $\mathrm{N}$ loss is ammonia volatilization, which is not only of public concern for its adverse impacts on health and the environment [4], but also represents a loss of $\mathrm{N}$ from organic fertilizers $[5,6]$. Thus, improving the use efficiency of manure-derived 
$\mathrm{N}$ is essential [7]. Diet management (e.g. acidifying pig diets) [8], management during storage (e.g. covering of the slurry tank) [9], and slurry application methods (e.g. injection or banding) $[6,10]$ have all been studied as ways for agricultural operations to minimize $\mathrm{NH}_{3}$ volatilization of animal manures and improve their $\mathrm{N}$ use efficiency. However, most results have often limited to evaluate the whole slurry management including gases emission, soil mineralization, and plant $\mathrm{N}$ use efficiency.

The $\mathrm{NH}_{3}$ in manure is generated from the hydrolysis of urinary urea, which is mediated by the microbial urease that is present in feces. The $\mathrm{NH}_{3}$ volatilization occurs when ammonium $\left(\mathrm{NH}_{4}^{+}\right)$is converted to a gas under alkaline conditions, accounting typically for $40 \%$ to $50 \%$ in housing (and pasture), $5 \%$ to $15 \%$ from storage, and $40 \%$ to $55 \%$ during land application [4]. Both aerobic nitrification, in which $\mathrm{NH}_{4}^{+}$is oxidized to $\mathrm{NO}_{2}{ }^{-}$and further $\mathrm{NO}_{3}{ }^{-}$, and anaerobic microbial denitrification, in which $\mathrm{NO}_{3}{ }^{-}$is reduced to gaseous nitrogen compounds, can generate $\mathrm{N}_{2} \mathrm{O}$, which is then released into the atmosphere $[11,12]$. The simple way to minimize $\mathrm{NH}_{3}$ and additional $\mathrm{N}_{2} \mathrm{O}$ emission is to create conditions that minimize the concentration of $\mathrm{NH}_{3}$ relative to those of $\mathrm{NH}_{4}{ }^{+}$, specifically by lowering slurry $\mathrm{pH}$, a process that has been developed, widely tested and recently reviewed [3]. The positive effects of slurry acidification in reducing $\mathrm{NH}_{3}$ and $\mathrm{N}_{2} \mathrm{O}$ emissions [13] as well as on field crop yields [14-16] have been widely reported. However, acids are highly corrosive and hazardous to use, unless diluted with water. Furthermore, spreading of acidified slurry on soil will increase soil acidification, and chemical scorching of crops following application of slurries containing nitric acid have been reported. A recent review by Fanguerio et al [13] revealed that the effects of slurry acidification on the mineral fertilizer equivalent (MFE) varied significantly in several studies. As such, there is a need to improve our understanding of the implications of increasing the use efficiencies of manure $\mathrm{N}$, and mitigating $\mathrm{NH}_{3}$ and $\mathrm{N}_{2} \mathrm{O}$ emissions and nitrate leaching, in order to achieve global targets.

The primary objective of this study was to determine the fate of pig slurry $\mathrm{N}$ to four major sinks: i) plant uptake, ii) soil $\mathrm{N}$ pool, iii) nitrogenous gases emission, and iv) nitrate leaching during regrowth of pasture sward. We emphasized the $\mathrm{N}$ flux derived from pig slurry urea because about 50\% to $60 \%$ of $\mathrm{N}$ is excreted in the urine by pigs and cows, and $65 \%$ to $90 \%$ of $\mathrm{N}$ in urine is present as urea [17]. In this study, the turnover of pig slurry ${ }^{15} \mathrm{~N}$-urea was directly quantified under the assumption that rates of microbial mineralization, nitrifica- tion, and denitrification were the same between labeled ${ }^{15} \mathrm{~N}$ urea and unlabeled ${ }^{14} \mathrm{~N}$-urea in pig slurry.

\section{MATERIALS AND METHODS}

\section{Site, weather condition and experimental design}

Field experiments were conducted on a permanent grass sward consisting mainly of perennial ryegrass (Lolium perenne), which was used for grass silage in the year preceding the treatment application. The experimental site was located in the uplands of southwestern South Korea $\left(\mathrm{E} 126^{\circ} 90^{\prime}, \mathrm{S} 35^{\circ} 18^{\prime}\right)$ and featured a sandy loamy soil, the properties of which are presented in Table 1 . The prevailing climate over the experimental period was humid temperate, with a mean temperature of $22.5^{\circ} \mathrm{C}$ and a total precipitation of $420 \mathrm{~mm}$. Three treatments were applied: i) untreated pig slurry, as a control; ii) slurry adjusted to neutral $\mathrm{pH}$ 7.0; and iii) acidified pig slurry adjusted to $\mathrm{pH}$ 5.0. The experimental design consisted of a randomized complete block design with four replications; each treatment block measured $2.5 \mathrm{~m} \times 10 \mathrm{~m}$. Adjacent blocks were separated by a $2-\mathrm{m}$ margin and bordered with $45-\mathrm{cm}$ metal retainers inserted $30-\mathrm{cm}$ deep into the soil to prevent surface runoff and cross-plot contamination. Each treatment block contained 12 micro-plots $(0.5 \mathrm{~m}$ $\times 0.5 \mathrm{~m}$ ) for monitoring the fate of ${ }^{15} \mathrm{~N}$-labeled pig slurry, four bottomless acrylic glass tubes $(20-\mathrm{cm}$ diameter and $30-\mathrm{cm}$ length) for collecting gas samples, and four suction cups (P80, eco Tech, Bonn, Germany) for collecting leachate samples.

\section{Pig slurry treatments and ${ }^{15} \mathrm{~N}$ labeling}

Slurry was collected from a local pig farm, where it was stored for approximately 1 week in a concrete tank at ambient temperatures, then placed into three different $400 \mathrm{~L}$ plastic containers. One container of the untreated slurry (control) was preserved at its original $\mathrm{pH}$ (7.9), whereas the slurries in the two other containers were acidified by slowly (to avoid foaming) adding $1.5 \mathrm{M} \mathrm{H}_{2} \mathrm{SO}_{4}$ until $\mathrm{pH} 7.0$ and $\mathrm{pH} 5.0$ were reached. The slurry urea fraction of the three treatments was labeled by thoroughly mixing ${ }^{15} \mathrm{~N}$ urea immediately prior to field application. Highly enriched ${ }^{15} \mathrm{~N}$ urea $\left(98 \%{ }^{15} \mathrm{~N}\right.$ atom excess) was used to minimize the portion of chemical urea for a target ${ }^{15} \mathrm{~N}$ urea enrichment of approximately 5.0 atom \%. Subsamples of the applied slurry were analyzed at the time of application (Table 1). The pig slurry contained on average $\left(\mathrm{kg} / \mathrm{m}^{3}\right) 1.63 \pm$ 0.11 total $\mathrm{N}, 0.197 \pm 0.012 \mathrm{NH}_{4}{ }^{+}-\mathrm{N}, 0.148 \pm 0.015 \mathrm{NO}_{3}{ }^{-}-\mathrm{N}, 0.78 \pm$ $0.02 \mathrm{P}$, and $1.04 \pm 0.01 \mathrm{~K}$ with $\mathrm{pH}_{\text {water }}(1: 5)$ of $7.9 \pm 0.02$.

Treated pig slurry was applied at a rate of $200 \mathrm{~kg} \mathrm{~N} / \mathrm{ha}$. For

Table 1. Nitrogenous composition and ${ }^{15} \mathrm{~N}$ atom $\%$ of the pig slurry used for experiment

\begin{tabular}{lccccc}
\hline $\mathrm{N}$ fraction & $\begin{array}{c}\text { Total N } \\
(\mathbf{g ~ N} / \mathrm{kg})\end{array}$ & $\begin{array}{c}\text { Urea } \\
(\mathbf{g} / \mathrm{kg})\end{array}$ & $\begin{array}{c}\mathrm{NH}_{4}{ }^{+}-\mathrm{N} \\
(\mathrm{mg} \mathrm{N} / \mathrm{kg})\end{array}$ & $\begin{array}{c}\mathrm{NO}_{3}{ }^{-}-\mathrm{N} \\
(\mathbf{m g ~ N} / \mathrm{kg})\end{array}$ & $\begin{array}{c}{ }^{15} \mathrm{~N} \text { atom excess } \\
(\%)\end{array}$ \\
\hline Pig slurry & $1.55 \pm 0.32$ & $0.96 \pm 0.12$ & $196.9 \pm 12$ & $148.4 \pm 9.0$ & $5.00122 \pm 0.00217$ \\
\hline
\end{tabular}

The values are mean \pm standard deviation of four replicates. 
the application of pig slurry, $307 \mathrm{~L}$ of pig slurry, which contained $95.8 \mathrm{~kg} \mathrm{P} / \mathrm{ha}$ and $127 \mathrm{~kg} \mathrm{~K} / \mathrm{ha}$, was applied to the $25-\mathrm{m}^{2}$ plots after herbage was cut at $5-\mathrm{cm}$ above ground level in the early spring (February 12).

\section{Herbage, soil, gases, and leachate sampling}

Soil and herbage samples were collected from the micro-plots bounded $0.5 \mathrm{~m} \times 0.5 \mathrm{~m}$ in a depth of $30 \mathrm{~cm}$ for soils) at 7, 14, and $56 \mathrm{~d}$ after cutting (e.g. application of pig slurry), respectively. Two earlier (7 and $14 \mathrm{~d}$ ) and one final (56 d after regrowth) sampling times were also considered based on previous reports, which showed that endogenous $\mathrm{N}$ stored in roots or stubble is a main source of $\mathrm{N}$ for the earliest 2 weeks of regrowth, whereas exogenously applied $\mathrm{N}$ is important for later periods of regrowth $[18,19]$. For herbage sampling, herbage mass was cut manually at each sampling day, leaving stubble of approximately $5-\mathrm{cm}$ at four randomly placed micro-plots in each treatment block. About $500 \mathrm{~g}$ of the harvested herbage tissue was sliced into $2-\mathrm{cm}$ long segments, which were then lyophilized, ground, and stored in a vacuum desiccator for further analysis. Soil sampling was conducted in the same micro-plots where herbage samples were collected, with soil cores (0 to 30 $\mathrm{cm}$ depth) taken randomly using a 3 -cm diameter tube auger. Soil samples were air-dried and finely milled to $<0.15 \mathrm{~mm}$.

Airtight acrylic glass chambers $(20-\mathrm{cm}$ diameter $\times 30-\mathrm{cm}$ depth) were inserted to a depth of $5 \mathrm{~cm}$ in the soil for gas sampling. To collect $\mathrm{NH}_{3}$ emission, acid trap system method described by Ndegwa [20] was adopted, with minor modifications. Each chamber was connected (via a septum located in the lid of the chamber) to $\mathrm{NH}_{3}-\mathrm{N}$ trapping bottles containing $150 \mathrm{~mL}$ of $0.2 \mathrm{~mol} / \mathrm{L} \mathrm{H}_{2} \mathrm{SO}_{4}$ (equivalent to 0.03 moles of acid). The other glass tube was connected to the vacuum system that created an airflow through the chambers at a constant rate of $1.5 \mathrm{~L}$ per min to exhaust the $\mathrm{NH}_{3}$-scrubbed air. Each chamber was closed and clamped with attached with silicon sealing for $24 \mathrm{~h}$. Sampling of $\mathrm{N}_{2} \mathrm{O}$ gas from the acrylic glass chamber was conducted from each closed chamber using a syringe just before the sampling of $\mathrm{NH}_{3}$ emission and then stored in $10 \mathrm{~mL}$ vacutainer tube prior to analysis. For the sampling $\mathrm{NH}_{3}$ emission, the vacuum was connected to pull the sweep-air in the chamber into the acid trap bottle. A pair of four parallel ammonia trapping systems in each treatment block was run concurrently over $1 \mathrm{~h}$ to avoid extraneous effects during gas collection. Potential $\mathrm{NH}_{3}$ emissions were determined daily for the first $15 \mathrm{~d}$, then at 1 to 2 week intervals afterward. The gas samples were taken. Four ceramic suction cup samplers (P80, eco Tech, Germany) were randomly positioned at depths of $50 \mathrm{~cm}$ for collecting soil water leachate for $\mathrm{NO}_{3}^{-}-\mathrm{N}$ analysis in each treatment block, with soil water samples obtained weekly under a tension of $-250 \mathrm{hPa}$ and stored at $-20^{\circ} \mathrm{C}$.

\section{Measurements and chemical analysis}

The biomass harvested from each micro-plot was converted to $\mathrm{kg} / \mathrm{ha}$. This estimate was multiplied by the $\mathrm{N}$ concentration determined in the subsamples in order to calculate the $\mathrm{N}$ recovery in herbage $(\mathrm{kg} \mathrm{N} / \mathrm{ha})$ at a given regrowth time. The total $\mathrm{N}$ content and ${ }^{15} \mathrm{~N}$ atom \% of herbage, soil, and pig slurry samples were measured with a stable isotope ratio mass spectrometer (IRMS, IsoPrime, GV Instrument, Manchester, UK). For determination of soil $\mathrm{NH}_{4}{ }^{+}-\mathrm{N}$ and $\mathrm{NO}_{3}{ }^{-} \mathrm{N}$, about $20 \mathrm{~g}$ of finely sieved soil was extracted with $250 \mathrm{~mL}$ of $2 \mathrm{M} \mathrm{KCl}$; extracts were then placed in distillation flasks and steam-distilled with $\mathrm{MgO}$ to ascertain the $\mathrm{NH}_{4}{ }^{+}$fraction. Samples in the flasks were then distilled again after addition of Devarda's alloy for $\mathrm{NO}_{3}{ }^{-}$determination. The $\mathrm{N}$ liberated from each distillation was collected in the form of $\mathrm{H}_{2} \mathrm{SO}_{4}$ to be a more stable form $\left(\mathrm{NH}_{4}\right)_{2} \mathrm{SO}_{4}$ for the evaporation procedure. These soluble fractions were acidified to $\mathrm{pH} 2$ to 3 to avoid possible loss through ammonia volatilization, and then evaporated to dryness. The dried powder, in the form of $\left(\mathrm{NH}_{4}\right)_{2} \mathrm{SO}_{4}$, was analyzed for the determination of $\mathrm{N}$ content and ${ }^{15} \mathrm{~N}$ atom $\%$ excess of each $\mathrm{N}$ fraction. Concentrations of total $\mathrm{N}, \mathrm{NH}_{4}^{+}-\mathrm{N}$, and $\mathrm{NO}_{3}^{-}-\mathrm{N}$ in soil samples were converted to $\mathrm{kg} \mathrm{N} / \mathrm{ha}$ using the soil bulk density determined from the soil cores. The concentration of $\mathrm{NH}_{3}-\mathrm{N}$ in the acid trap solution (e.g. ammonium sulfate) was colorimetrically determined with Nessler's ammonium color reagent after microdiffusion in a Conway dish [21] and expressed as the content of $\mathrm{NH}_{3}-\mathrm{N}$ emitted per hectare. The $\mathrm{N}_{2} \mathrm{O}$ concentration were analyzed by a gas chromatograph (7890A, Agilent technologies, Santa Clara, CA, USA) equipped with a thermal conductivity detector. Separation was achieved with a HP-Plot 5 A column $(30 \mathrm{~m} \times 0.53 \mathrm{~mm} \times 25 \mu \mathrm{m})$ using helium as the carrier gas, at a flow rate of $2 \mathrm{~mL} / \mathrm{min}$. The $\mathrm{N}_{2} \mathrm{O}$ fluxes were calculated as described by Guo et al [22]. Cumulative $\mathrm{NH}_{3}$ and $\mathrm{N}_{2} \mathrm{O}$ emissions over the entire experimental period were calculated by summing all daily measurements and period estimations (number of day $\times$ mean flux between sampling dates). Concentrations of $\mathrm{NO}_{3}{ }^{-}-\mathrm{N}$ in leachates were determined via ion chromatography (Dionex, DX-120, Sunnyvale, CA, USA), as previously described [23].

\section{Calculation}

The measured ${ }^{15} \mathrm{~N}$ atom $\%$ excess abundances in the total $\mathrm{N}$, $\mathrm{NH}_{4}^{+}$, and $\mathrm{NO}_{3}^{-}$fractions in herbage and soil samples were converted to relative specific activity (RSA, i.e. \% of recently incorporated atoms relative to the total number of atoms in the sample) using equation (1):

$$
\begin{aligned}
\mathrm{RSA}= & \left({ }^{15} \mathrm{~N}\right. \text { atom \% in herbage sample of labeled plot } \\
& - \text { natural abundance of herbage }) \\
& / \text { (atom \% } 15 \mathrm{~N} \text {-urea of applied pig slurry } \\
& - \text { natural abundance of pig slurry) } \\
& \times 100
\end{aligned}
$$


In which the natural abundance of herbage and pig slurry was adopted from the ${ }^{15} \mathrm{~N}$ atom $\%$ of non $-{ }^{15} \mathrm{~N}$-fed herbage and that of unlabeled pig slurry. The amount of $\mathrm{N}$ derived from the urea of applied pig slurry (NdfSU) in herbage samples was calculated via equation (2):

$$
\begin{array}{r}
\mathrm{NdfSU}=(\mathrm{RSA} \times \mathrm{N} \text { content measured in a herbage sample }) \\
/ 100 \quad \text { (Equ. } 2)
\end{array}
$$

Similar equations were applied for the total $\mathrm{N}, \mathrm{NH}_{4}{ }^{+}$, and $\mathrm{NO}_{3}{ }^{-}$fractions in the soil samples. The percentage of slurry urea- $\mathrm{N}$ recovered in the total $\mathrm{N}, \mathrm{NH}_{4}{ }^{+}$, and $\mathrm{NO}_{3}^{-}$fractions in herbage and soil samples was calculated by the ratio between the NdfSU and the quantity of applied N. The percentage of loss therefore refers to the portion that was not recovered in herbage and soil.

\section{Statistical analysis}

Analysis of variation was conducted to assess the effects of acidification of pig slurry at each sampling time on herbage yield, N uptake, and fate of slurry urea-N. Significant differences among acidification treatments were tested using Duncan's multiple range test at the $5 \%$ level of probability using SAS 9.1.3 software [24].

\section{RESULTS AND DISCUSSION}

Soil $\mathrm{pH}$, herbage dry matter, and $\mathrm{N}$ uptake

The initial soil $\mathrm{pH}$ of the experimental plots averaged 5.54 \pm 0.41 . The $\mathrm{pH}$ in the non-pH-controlled (control) plots and those in the $\mathrm{pH}$-controlled pig slurry plots set to $\mathrm{pH} 7$ slightly increased during the initial 7 to $14 \mathrm{~d}$ and then decreased to 6.31 and 5.90 at the end of the measurement period ( $56 \mathrm{~d}$ after pig slurry application), respectively, whereas $\mathrm{pH}$ remained within the 5.51 to 5.72 range in the plots to which acidified pig slurry was applied ( $\mathrm{pH}$ 5) (Table 2). This implies that the increase in $\mathrm{pH}$ over the initial days following pig slurry application was offset by the acidifying effect of $\mathrm{N}$ sources and $\mathrm{CO}_{2}$ formed from mineralization of organic material, thus, ensuring that soil $\mathrm{pH}$ would be relatively stable for the latter experimental period.

A previous study revealed that $\mathrm{N}$ fertilization with pig slurry significantly enhanced the annual dry matter (DM) yield by $135 \%$ in a four-cut regime of perennial ryegrass sward compared to the non-fertilized control [25]. Positive $\mathrm{N}$ use efficiencies of animal slurry have been widely reported for herbage yields of pasture [6] and field crop productivity [26]. However, slurry application to soil promotes $\mathrm{NH}_{3}$ volatilization, which represents not only an $\mathrm{N}$ fertilizing value, but is also of concern for its adverse environmental impacts [7]. Although slurry acidification has been widely adopted to minimize $\mathrm{NH}_{3}$ emission, plant growth responses to acidified slurry application to soil has been poorly documented. In the present study, at $56 \mathrm{~d}$ of regrowth, mean herbage yield over the three plots receiving pig slurry with or without $\mathrm{pH}$ control was $3,345 \mathrm{~kg} \mathrm{DM} / \mathrm{ha}$, or $34.4 \%$ higher than that obtained from the first regrowth in the non-fertilized perennial ryegrass sward [25]. The impact of acidification on herbage regrowth was low throughout the regrowth period, as shown a significant reduction of herbage dry weight only in the $\mathrm{pH} 5$ plots at $14 \mathrm{~d}$ (Table 3).

Consistent with regrowth yield, the total amount of $\mathrm{N}$ taken up by herbage regrowth for $56 \mathrm{~d}$ of regrowth was not signifi-

Table 2. Changes in soil pH in the plot applied with untreated pig slurry (control), acidified (pH 5) or mutualized slurry (pH 7) during regrowth of perennial ryegrass sward

\begin{tabular}{lcccc}
\hline & Day 0 & Day 7 & Day 14 & Day 56 \\
\hline Control & $5.71 \pm 0.05^{\mathrm{a}}$ & $6.24 \pm 0.04^{\mathrm{a}}$ & $6.31 \pm 0.06^{\mathrm{a}}$ & $5.92 \pm 0.04^{\mathrm{a}}$ \\
pH 7 & $5.61 \pm 0.04^{\mathrm{a}}$ & $6.21 \pm 0.06^{\mathrm{a}}$ & $6.18 \pm 0.06^{\mathrm{a}}$ & $5.99 \pm 0.02^{\mathrm{a}}$ \\
pH 5 & $5.72 \pm 0.06^{\mathrm{a}}$ & $5.64 \pm 0.03^{\mathrm{b}}$ & $5.91 \pm 0.05^{\mathrm{b}}$ & $5.51 \pm 0.06^{\mathrm{b}}$ \\
\hline
\end{tabular}

The values are mean \pm standard deviation of four replicates.

a,b Different letters in horizontal row indicate significantly different at $p<0.05$ according to the Duncan's multiple range test.

Table 3. Total nitrogen content and the amount of $\mathrm{N}$ derived from slurry urea (NdfSU) in herbage as affected by the pH of pig slurry during regrowth of perennial ryegrass

\begin{tabular}{|c|c|c|c|c|c|c|c|c|c|}
\hline \multirow[b]{2}{*}{ Treatment } & \multicolumn{3}{|c|}{ Day 7} & \multicolumn{3}{|c|}{ Day 14} & \multicolumn{3}{|c|}{ Day 56} \\
\hline & $\begin{array}{c}\text { DM } \\
\text { (kg/ha) }\end{array}$ & $\begin{array}{c}\text { Total N } \\
\text { (kg N/ha) }\end{array}$ & $\begin{array}{c}\text { NdfSU } \\
\text { (kg N/ha) }\end{array}$ & $\begin{array}{c}\text { DM } \\
\text { (kg/ha) }\end{array}$ & $\begin{array}{c}\text { Total N } \\
\text { (kg N/ha) }\end{array}$ & $\begin{array}{c}\text { NdfSU } \\
\text { (kg N/ha) }\end{array}$ & $\begin{array}{c}\text { DM } \\
\text { (kg/ha) }\end{array}$ & $\begin{array}{c}\text { Total N } \\
\text { (kg N/ha) }\end{array}$ & $\begin{array}{c}\text { NdfSU } \\
\text { (kg N/ha) }\end{array}$ \\
\hline Control & $268 \pm 6^{a}$ & $11.7 \pm 0.4^{\mathrm{a}}$ & $8.0 \pm 0.7^{a}$ & $942 \pm 115^{a}$ & $39.9 \pm 3.7^{\mathrm{a}}$ & $15.2 \pm 1.3^{\mathrm{a}}$ & $3,382 \pm 90^{\mathrm{a}}$ & $103 \pm 9.8^{\mathrm{a}}$ & $40.8 \pm 2.2$ \\
\hline pH 7 & $258 \pm 9^{a}$ & $10.4 \pm 0.4^{b}$ & $8.8 \pm 0.6^{a}$ & $895 \pm 57^{a}$ & $37.1 \pm 2.3^{\mathrm{a}}$ & $16.2 \pm 1.1^{\mathrm{ab}}$ & $3,434 \pm 140^{\mathrm{a}}$ & $114 \pm 8.8^{\mathrm{a}}$ & $54.8 \pm 3.1$ \\
\hline pH 5 & $254 \pm 3^{\mathrm{a}}$ & $10.1 \pm 0.1^{b}$ & $8.6 \pm 0.5^{a}$ & $746 \pm 29^{a}$ & $32.2 \pm 1.6^{b}$ & $13.8 \pm 0.8^{b}$ & $3,220 \pm 61^{a}$ & $110 \pm 8.4^{a}$ & $57.4 \pm 3.7$ \\
\hline
\end{tabular}
sward

DM, dry matter.

The values are mean \pm standard deviation of four replicates.

${ }^{a, b}$ Different letters in horizontal row indicate significantly different at $p<0.05$ according to the Duncan's multiple range test. 
cantly different ( $\mathrm{p}>0.05)$, with the exception of the $\mathrm{pH} 5$ plots at $14 \mathrm{~d}$ (Table 3). The amount of $\mathrm{N}$ derived from slurry urea (NdfSU) in herbage showed similar pattern with that of total herbage $\mathrm{N}$ up to $14 \mathrm{~d}$ (9.2\% decrease in $\mathrm{pH} 5$ plot compared to control). The mean NdfSU across the three treatments was $8.5 \mathrm{~kg} \mathrm{~N} / \mathrm{ha}$, a rather low value due to the high concentrations of inorganic $\mathrm{N}$ available in the soil. This may reflect a common physiological pattern characterized by low $\mathrm{N}$ uptake for the earlier regrowth period $[18,19]$. Nitrogen uptake was previously shown to gradually increase with progressing regrowth in perennial ryegrass swards to which cattle slurry was applied through three cycles of regrowth [6]. Likewise, it was demonstrated, via ${ }^{15} \mathrm{~N}$ tracing, that $\mathrm{N}$ release from applied organic amendments and $\mathrm{N}$ uptake by Chinese cabbage were more distinct in latter growth periods than during the earliest $30 \mathrm{~d}$ [27]. The final NdfSU in herbage at $56 \mathrm{~d}$ was significantly higher in both the $\mathrm{pH} 7(+34.3 \%)$ and $\mathrm{pH} 5(+40.7 \%)$ plots than in the controls (Table 3 ), suggesting that acidified pig slurry may release plant available $\mathrm{N}$ more slowly.

\section{Soil N dynamics}

Common finding that the enhanced growth and $\mathrm{N}$ uptake by plants in organic manure $\mathrm{N}$ fertilized soil than in non-fertilized soils $[5,6,25,27]$ could be attributed to the inorganic $\mathrm{N}$ released from organic $\mathrm{N}$ rather than the $\mathrm{N}$ pool size. Indeed, $\mathrm{pH}$ control of pig slurry did not affect the $\mathrm{N}$ pool size in the soil, as shown no significant differences among the three treatments throughout the entire regrowth period (Table 4). In the present study, a gradual decrease in ${ }^{15} \mathrm{~N}$ atom $\%$ in the soils treated with pig slurry (data not shown) suggested that $\mathrm{N}$ released from the applied ${ }^{15} \mathrm{~N}$-urea in pig slurry diluted the soil inorganic $\mathrm{N}$ pool, and thus more $\mathrm{N}$ was available for plant uptake. Thus, the relatively higher NdfSU in herbage at $56 \mathrm{~d}$ in the $\mathrm{pH}$-controlled plots ( $\mathrm{pH} 7$ and $\mathrm{pH}$ 5, Table 2) may be due to the higher availability of $\mathrm{N}$ to plants resulting from the mineralization of the organic $\mathrm{N}$ in pig slurry, as evidenced by the higher levels of NdfSU in the soil (Table 4).

Concentrations of soil $\mathrm{NH}_{4}^{+}-\mathrm{N}$ in the $\mathrm{pH} 7$ and $\mathrm{pH} 5$ plots significantly increased, by $9.5 \%$ and $23.2 \%$, respectively, at 7 $\mathrm{d}$ after pig slurry application, with the highest content found in the $\mathrm{pH} 5$ plots by $56 \mathrm{~d}$ (Table 4). The amount of $\mathrm{N}$ derived from slurry urea into the soil $\mathrm{NH}_{4}{ }^{+}$fraction (NdfSU- $\mathrm{NH}_{4}^{+}$) was significantly higher in the $\mathrm{pH} 5$ plot during the whole period of regrowth, while no significant difference was found between the control plots and $\mathrm{pH} 7$ plot until $14 \mathrm{~d}$. Levels of NdfSU- $\mathrm{NH}_{4}{ }^{+}$at $56 \mathrm{~d}$ were higher in both $\mathrm{pH} 7(+44.4 \%)$ and pH 5 (+61.1\%) plots than in the controls (Table 4). Concentrations of both $\mathrm{NH}_{4}+-\mathrm{N}$ and NdfSU- $\mathrm{NH}_{4}{ }^{+}$decreased in the soil with progressing regrowth as nitrification occurred, but the decline was slower in the $\mathrm{pH} 5$ plots. Our results were similar to those of previous laboratory incubation studies $[13,28]$ and field experiments [29] that examined the effects of acidified pig and cattle slurry applied to different types of soils.

The initial concentration of $\mathrm{NO}_{3}^{-}-\mathrm{N}$ in the soil was $36.2 \pm$ $2.1 \mathrm{~kg} / \mathrm{ha}$ and then increased during 56 days of regrowth in all treatment. Acidification led to significant reductions in the soil $\mathrm{NO}_{3}^{-}-\mathrm{N}$ pool by $14 \mathrm{~d}$. The amount of $\mathrm{N}$ derived from slurry urea into the soil $\mathrm{NO}_{3}{ }^{-}$fraction (NdfSU- $\mathrm{NO}_{3}{ }^{-}$) responded more quickly to pig slurry acidification, as shown by the significant decrease from $7 \mathrm{~d}$ (Table 3). Retention of higher levels of $\mathrm{NH}_{4}^{+}$and NdfSU-NH${ }_{4}^{+}$in soils amended with acidified slurry, which are adversely lower $\mathrm{NO}_{3}{ }^{-}$and $\mathrm{NdfSU}-\mathrm{NO}_{3}{ }^{-}$until $14 \mathrm{~d}$, suggested that acidification may delay or inhibit nitrification of $\mathrm{NH}_{4}^{+}-\mathrm{N}$ in the soil, in accordance with previous findings $[13,14,28]$. In the present study, no significant differences in $\mathrm{NO}_{3}{ }^{-}$and NdfSU-NO${ }_{3}^{-}$were detected between control plots

Table 4. The content of nitrogen fraction and the amount of $\mathrm{N}$ derived from slurry urea in each fraction as affected by the pH of pig slurry during regrowth of perennial ryegrass sward

\begin{tabular}{|c|c|c|c|c|c|c|}
\hline \multirow[b]{2}{*}{ Treatment } & \multicolumn{2}{|c|}{ Day 7} & \multicolumn{2}{|c|}{ Day 14} & \multicolumn{2}{|c|}{ Day 56} \\
\hline & $\begin{array}{l}\text { Nitrogen } \\
\text { (kg N/ha) }\end{array}$ & $\begin{array}{c}\text { NdfSU } \\
\text { (kg N/ha) }\end{array}$ & $\begin{array}{l}\text { Nitrogen } \\
\text { (kg N/ha) }\end{array}$ & $\begin{array}{c}\text { NdfSU } \\
\text { (kg N/ha) }\end{array}$ & $\begin{array}{l}\text { Nitrogen } \\
\text { (kg N/ha) }\end{array}$ & $\begin{array}{c}\text { NdfSU } \\
\text { (kg N/ha) }\end{array}$ \\
\hline Control & $1,958 \pm 60^{\mathrm{a}}$ & $129.2 \pm 7.8^{\mathrm{a}}$ & $1,894 \pm 145^{\mathrm{a}}$ & $1,16.8 \pm 8.8^{\mathrm{a}}$ & $1,755 \pm 124^{a}$ & $80.2 \pm 5.6^{b}$ \\
\hline pH 7 & $1,984 \pm 98^{\mathrm{a}}$ & $134.4 \pm 6.8^{\mathrm{a}}$ & $1,849 \pm 136^{a}$ & $122.8 \pm 8.6^{\mathrm{a}}$ & $1,705 \pm 112^{\mathrm{a}}$ & $82.4 \pm 7.9^{\mathrm{ab}}$ \\
\hline pH 5 & $1,974 \pm 48^{\mathrm{a}}$ & $137.4 \pm 8.3^{\mathrm{a}}$ & $1,907 \pm 105^{\mathrm{a}}$ & $129.6 \pm 9.5^{\mathrm{a}}$ & $1,717 \pm 108^{a}$ & $85.0 \pm 6.2^{a}$ \\
\hline Control & $158.1 \pm 9.5^{c}$ & $54.8 \pm 3.7^{b}$ & $100.6 \pm 9.2^{b}$ & $26.4 \pm 0.9^{b}$ & $26.6 \pm 2.1^{b}$ & $1.8 \pm 0.1^{c}$ \\
\hline pH 7 & $173.8 \pm 8.9^{b}$ & $57.6 \pm 3.8^{b}$ & $109.1 \pm 9.8^{\mathrm{ab}}$ & $27.6 \pm 1.2^{\mathrm{ab}}$ & $34.7 \pm 0.7^{\mathrm{ab}}$ & $2.6 \pm 0.1^{a b}$ \\
\hline pH 5 & $194.8 \pm 9.3^{\mathrm{a}}$ & $67.2 \pm 4.1^{\mathrm{a}}$ & $124.7 \pm 8.4^{\mathrm{a}}$ & $30.2 \pm 1.4^{a}$ & $38.8 \pm 1.7^{\mathrm{a}}$ & $2.9 \pm 0.2^{\mathrm{a}}$ \\
\hline \multicolumn{7}{|l|}{$\mathrm{NO}_{3}-\mathrm{N}$} \\
\hline Control & $52.7 \pm 2.7^{\mathrm{a}}$ & $8.8 \pm 0.5^{a b}$ & $100.4 \pm 3.2^{\mathrm{a}}$ & $34.2 \pm 0.8^{\mathrm{a}}$ & $158.9 \pm 9.6^{a}$ & $59.2 \pm 3.9^{a}$ \\
\hline pH 7 & $52.0 \pm 3.6^{a}$ & $9.8 \pm 0.6^{a}$ & $103.2 \pm 3.3^{\mathrm{a}}$ & $32.4 \pm 1.2^{\mathrm{a}}$ & $145.4 \pm 8.8^{\mathrm{ab}}$ & $53.8 \pm 2.9^{\mathrm{ab}}$ \\
\hline
\end{tabular}

The values are mean \pm standard deviation of four replicates.

${ }^{a-c}$ Different letters in horizontal row indicate significantly different at $p<0.05$ according to the Duncan's multiple range test. 
and $\mathrm{pH} 7$ plots. Given that the activity of nitrifying bacteria is strongly inhibited when soil pH is lower than 6 [30], application of $\mathrm{pH} 7$ slurry had little effect on microbial nitrification rates because soil pH in these plots remained above 5.8.

\section{Recovery of pig slurry urea $-{ }^{15} \mathrm{~N}$}

At the end of regrowth ( $56 \mathrm{~d}$ after pig slurry application), the percentage slurry urea- ${ }^{15} \mathrm{~N}$ recovered in herbage and soil averaged over all treatments was $25.5 \%$ and $41.3 \%$, respectively; thus, $33.2 \%$ was unaccounted for and designated as loss (Table 5). The percentage of slurry urea ${ }^{15} \mathrm{~N}$ by herbage in the $\mathrm{pH} 5$ plots was significantly lower at $14 \mathrm{~d}$, after which it increased at the highest rate. This may reflect the increased $\mathrm{N}$ availability released from slurry urea relative to the non-acidified treatments (Table 3). The positive effects of slurry acidification on plant nutrient availability through estimations of the MFE have been previously reported [14,29], as higher levels of MFE in soils amended with acidified slurry was shown to significantly increase annual crop yields [14-16]; in addition, acidified slurry application led to higher herbage yields in permanent grasslands [31].

The percentage of slurry urea- ${ }^{15} \mathrm{~N}$ recovery in total soil $\mathrm{N}$ gradually decreased, from $66.8 \%$ (mean of three treatments) at $7 \mathrm{~d}$ to $41.3 \%$ at $56 \mathrm{~d}$, without significant influence of slurry $\mathrm{pH}$ treatment. However, the effect of acidification on soil inorganic $\mathrm{N}$ recovery varied with time after application, as shown by the higher soil $\mathrm{NH}_{4}{ }^{+}$recovery throughout the whole period while lower soil $\mathrm{NO}_{3}{ }^{-}$recovery for the earlier $14 \mathrm{~d}$ relative to non-acidified treatments. The percentage slurry urea $-{ }^{15} \mathrm{~N}$ recovered in soil inorganic $\mathrm{N}\left(\mathrm{NH}_{4}^{+}\right.$plus $\left.\mathrm{NO}_{3}^{-}\right)$at $56 \mathrm{~d}$ was $25.5 \%, 28.2 \%$, and $27.1 \%$, respectively, in the control, $\mathrm{pH} 7$, and $\mathrm{pH} 5$ plots. Urea-N has often been reported to have lower $\mathrm{N}$ use efficiency for DM production per $\mathrm{kg}$ of applied $\mathrm{N}$ compared to other ammonium- and nitrate-based fertilizers [32,33]. In this study, the percentage of slurry urea- ${ }^{15} \mathrm{~N}$ not recovered in herbage and soil (designated as $\mathrm{N}$ loss) was within the range of $27.0 \%$ to $39.5 \%$ over the three treatments throughout the experimental period. Several ${ }^{15} \mathrm{~N}$-urea tracing studies estimated $\mathrm{N}$ losses of $20 \%$ to $37 \%$ in wheat treated with ureases and/or nitrification inhibitors [32], 20\% to $35 \%$ in maize [34], and $24 \%$ to $40 \%$ in Chinese cabbage [27] grown in soils amended with different levels of organic $\mathrm{N}$. Taking the full $\mathrm{N}$ cycle in agroecosystems into consideration, $\mathrm{N}$ losses include gaseous $\mathrm{N}$ emissions in the form of ammonia $\left(\mathrm{NH}_{3}\right)$, nitric oxide $(\mathrm{NO})$, nitrous oxide $\left(\mathrm{N}_{2} \mathrm{O}\right)$, and molecular $\mathrm{N}\left(\mathrm{N}_{2}\right)$, as well as nitrate leaching and immobilization to organic $\mathrm{N}$ by microorganisms. Our results clearly show that acidification significantly reduced $\mathrm{N}$ loss from pig slurry $\mathrm{N}$ applied to perennial ryegrass sward.

\section{$\mathrm{NH}_{3}, \mathrm{~N}_{2} \mathrm{O}$ emission, and $\mathrm{NO}_{3}{ }^{-}$leaching}

$\mathrm{NH}_{3}$ emissions following animal manure application to soil derive from the decomposition of $\mathrm{N}$ present in the feces and hydrolysis of urea, mainly in form of urine. Urea hydrolysis is mediated by the enzyme urease and produces ammonium and carbonate. In soils amended with animal manure, significant increases in the daily $\mathrm{NH}_{3}$ flux have been shown to occur in various cropping systems $[13,14,28]$ and laboratory incubation assays [35,36]. One primary goal of acidification of animal slurries is to reduce $\mathrm{NH}_{3}$ emissions, because of its negative impacts on both the environment and animal health $[14,37]$. Gaseous $\mathrm{NH}_{3}$ may be formed depending in the $\mathrm{pH}$ value of the slurry-soil system. Hydrolysis of urea can take place both under aerobic and anaerobic conditions, with optimum $\mathrm{pH}$ levels for urease activity between 6.5 and 7.0 [38]. In the present study, more than $50 \%$ of total $\mathrm{NH}_{3}$ emissions occurred within the first $14 \mathrm{~d}$ after application to the soil in all treatments. Daily $\mathrm{NH}_{3}$ emissions for this period decreased significantly in the $\mathrm{pH} 5$ plots relative to the control and $\mathrm{pH} 7$ plots (Figure 1A), confirming that the final $\mathrm{pH}$ of slurry is directly associated with $\mathrm{NH}_{3}$ emissions following slurry appli-

Table 5. Recovery percentage of pig slurry urea- ${ }^{15} \mathrm{~N}$ in herbage and soil, and calculated loss (not recover in herbage or soil) as affected by $\mathrm{pH}$ control of pig slurry during regrowth of perennial ryegrass sward

\begin{tabular}{|c|c|c|c|c|c|c|}
\hline \multirow{2}{*}{ Date } & \multirow{2}{*}{ Treatment } & \multirow{2}{*}{ Herbage } & \multicolumn{3}{|c|}{ Soil } & \multirow{2}{*}{ Loss } \\
\hline & & & Total N & $\left(\mathrm{NH}_{4}^{+}-\mathrm{N}\right)$ & $\left(\mathrm{NO}_{3}^{-}-\mathrm{N}\right)^{1)}$ & \\
\hline \multirow[t]{3}{*}{ Day 7} & Control & $4.0 \pm 0.2^{a}$ & $64.6 \pm 4.1^{\mathrm{a}}$ & $\left(27.4 \pm 1.4^{b}\right)$ & $\left(4.4 \pm 1.4^{\mathrm{ab}}\right)$ & $31.4 \pm 2.8^{a}$ \\
\hline & pH 7 & $4.4 \pm 0.2^{a}$ & $67.2 \pm 5.2^{\mathrm{a}}$ & $\left(28.8 \pm 1.6^{b}\right)$ & $\left(4.9 \pm 1.4^{\mathrm{a}}\right)$ & $28.4 \pm 3.6^{a}$ \\
\hline & pH 5 & $4.3 \pm 0.1^{\mathrm{a}}$ & $68.7 \pm 4.7^{\mathrm{a}}$ & $\left(33.6 \pm 1.9^{a}\right)$ & $\left(4.1 \pm 1.4^{b}\right)$ & $27.0 \pm 3.3^{\mathrm{ab}}$ \\
\hline \multirow[t]{3}{*}{ Day 14} & Control & $7.6 \pm 0.5^{\mathrm{a}}$ & $58.4 \pm 4.2^{a}$ & $\left(13.2 \pm 0.7^{b}\right)$ & $\left(17.1 \pm 1.1^{\mathrm{a}}\right)$ & $34.0 \pm 2.9^{a}$ \\
\hline & pH 7 & $8.1 \pm 0.5^{\mathrm{ab}}$ & $61.4 \pm 3.9^{\mathrm{a}}$ & $\left(13.8 \pm 0.9^{\mathrm{ab}}\right)$ & $\left(16.2 \pm 1.0^{\mathrm{a}}\right)$ & $30.5 \pm 2.5^{\mathrm{ab}}$ \\
\hline & pH 5 & $6.9 \pm 0.4^{b}$ & $64.8 \pm 4.7^{\mathrm{a}}$ & $\left(15.1 \pm 1.0^{\mathrm{a}}\right)$ & $\left(12.5 \pm 0.8^{b}\right)$ & $28.3 \pm 2.4^{b}$ \\
\hline \multirow[t]{3}{*}{ Day 56} & Control & $20.4 \pm 1.5^{b}$ & $40.1 \pm 2.4^{a}$ & $\left(0.9 \pm 0.1^{c}\right)$ & $\left(24.6 \pm 1.6^{b}\right)$ & $39.5 \pm 2.9^{a}$ \\
\hline & pH 7 & $27.4 \pm 1.4^{\mathrm{a}}$ & $41.2 \pm 1.9^{\mathrm{a}}$ & $\left(1.3 \pm 0.1^{\mathrm{ab}}\right)$ & $\left(26.9 \pm 1.4^{a}\right)$ & $31.4 \pm 2.9^{b}$ \\
\hline & pH 5 & $28.7 \pm 1.7^{\mathrm{a}}$ & $42.5 \pm 2.1^{\mathrm{a}}$ & $\left(1.5 \pm 0.2^{a}\right)$ & $\left(25.6 \pm 1.2^{a b}\right)$ & $28.8 \pm 2.9^{b}$ \\
\hline
\end{tabular}

\footnotetext{
1) Percentage of pig slurry urea ${ }^{-15} \mathrm{~N}$ in soil inorganic $\mathrm{N}\left(\mathrm{NH}_{4}^{+}-\mathrm{N}\right.$ or $\left.\mathrm{NO}_{3}{ }^{-} \mathrm{N}\right)$.

The values are mean \pm standard deviation of four replicates.

${ }^{a-c}$ Different letters in horizontal row indicate significantly different at $p<0.05$ according to the Duncan's multiple range test.
} 

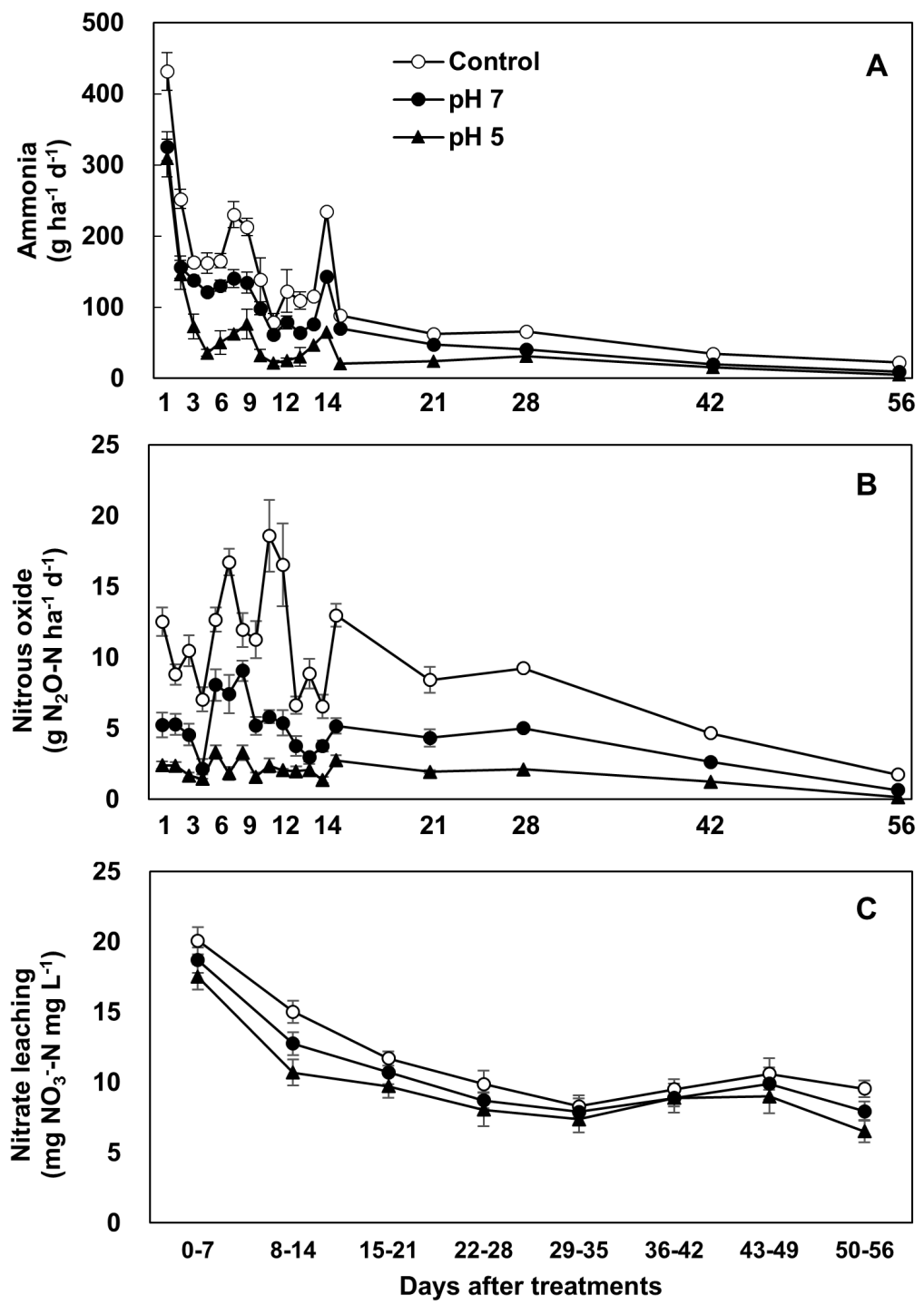

Figure 1. Daily emission of ammonia (A) and nitrous oxide (B), and weekly accumulative nitrate concentration in leachate $\left(\mathrm{mg} \mathrm{NO}_{3}{ }^{-}-\mathrm{N} / \mathrm{L}, \mathrm{C}\right)$ from the soil amended with untreated (control, o), mutualized $(\mathrm{pH} 7, \bullet)$ and acidified pig slurry $(\mathrm{pH} 5, \mathbf{\Delta})$ during regrowth of perennial ryegrass sward. The values are mean \pm standard deviation of four replicates.

cation to soil $[13,29,39]$. Cumulative $\mathrm{NH}_{3}$ emissions throughout the period of measurement decreased by $60.9 \%$ in the $\mathrm{pH} 5$ plots but by only $33.7 \%$ in the $\mathrm{pH} 7$ plots compared to the control plots (Figure 2A). Previous work has shown that the efficacy of slurry acidification in reducing $\mathrm{NH}_{3}$ emissions after field application varied within the range of $40 \%$ to $80 \%$ for pig slurry $[40,41]$ and $15 \%$ to $80 \%$ for cattle slurry $[28,42,43]$ applications, depending on the target $\mathrm{pH}$ and/or the types of acids used.

Nitrous oxide emissions from soils amended with animal slurry result from the nitrification and denitrification processes. The main determinants of $\mathrm{N}_{2} \mathrm{O}$ emissions are thus the amount of $\mathrm{NH}_{4}{ }^{+}$available for nitrification to $\mathrm{NO}_{3}{ }^{-}$and the amount of soluble organic $\mathrm{C}$ available for denitrification. Consistent with $\mathrm{NH}_{3}$ emissions, daily $\mathrm{N}_{2} \mathrm{O}$ emissions were lower over the first
$14 \mathrm{~d}$ in the $\mathrm{pH} 5$ plots, and remained lower than in the control and $\mathrm{pH} 7$ plots up to $56 \mathrm{~d}$ (Figure 1B). Cumulative $\mathrm{N}_{2} \mathrm{O}$ emissions throughout the period of measurement decreased by $71.8 \%$ in the $\mathrm{pH} 5$ plots but by only $48.7 \%$ in the $\mathrm{pH} 7$ plots compared to the controls (Figure 2B). The results of the limited number of studies of the effects of slurry acidification on $\mathrm{N}_{2} \mathrm{O}$ emissions relative to $\mathrm{NH}_{3}$ emissions are inconsistent. Velthof and Oenema [44], for instance, reported that $\mathrm{N}_{2} \mathrm{O}$ emissions increased following acidified slurry application compared with $\mathrm{HNO}_{3}$ emissions in grasslands, which they attributed to the addition of $\mathrm{NO}_{3}{ }^{-}$rather than to the $\mathrm{pH}$ of slurry. In contrast, other studies have shown that slurry acidification reduced $\mathrm{N}_{2} \mathrm{O}$ emissions during storage [45] and after soil application of acidified pig slurry [35]. In laboratory incubation assays, $\mathrm{N}_{2} \mathrm{O}$ emissions from acidified cattle slurry were 

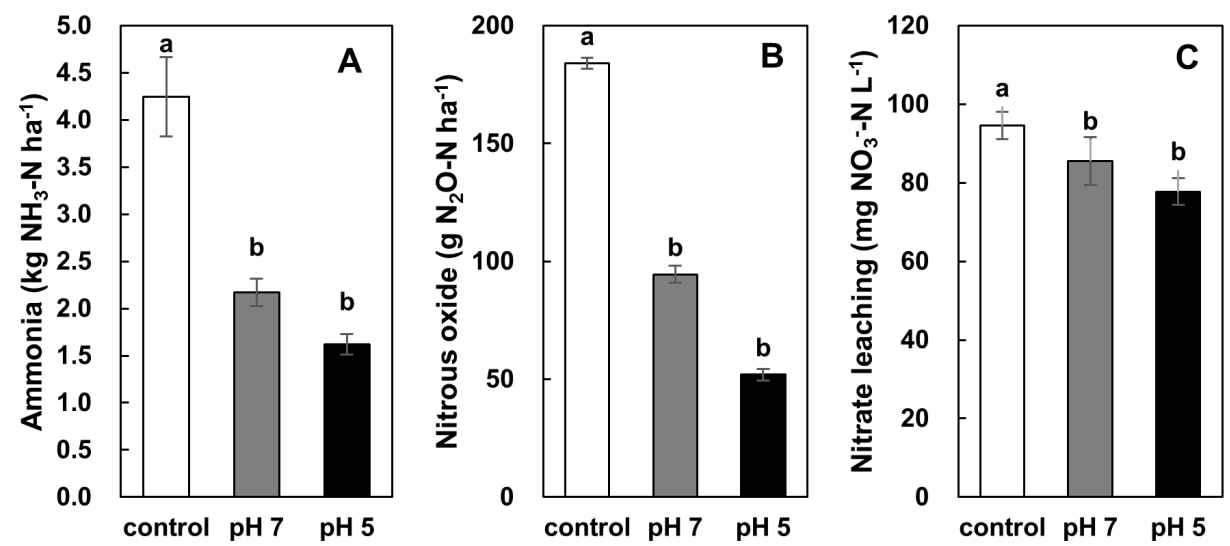

Figure 2. Total emission of ammonia (A) and nitrous oxide (B) and nitrate leaching (C), as estimated by cumulative amount for 56 days of regrowth. The values are mean \pm standard deviation of four replicates. Different letters in horizontal row indicate significantly different at $p<0.05$ according to the Duncan's multiple range test.

significantly decreased relative to non-acidified slurry [13]. Fangueiro et al [35] attributed a decrease in $\mathrm{N}_{2} \mathrm{O}$ emissions following slurry application to a delay in or inhibition of the nitrification process. This interpretation is well consistent with our results, which show lower $\mathrm{NO}_{3}{ }^{-}$concentrations and NdfSU$\mathrm{NO}_{3}{ }^{-}$in soils amended with acidified pig slurry for the first $14 \mathrm{~d}$ (Table 4). The lower $\mathrm{N}_{2} \mathrm{O}$ emission from acidified slurry may be due to the reduced amount of organic $\mathrm{C}$ available for denitrification resulting from $\mathrm{CO}_{2}$ losses during the acidification process [13].

The $\mathrm{NH}_{4}{ }^{+}$in mineral $\mathrm{N}$ and organic manure is rapidly nitrified in soil after application $[5,46]$. The surplus $\mathrm{N}$, after converting to $\mathrm{NO}_{3}{ }^{-}$, is prone to leaching when there is drainage. This process depends on the mineralization dynamics of soil $\mathrm{N}$, as well as soil moisture and temperature [24,47]. We found that the weekly cumulative leaching of $\mathrm{NO}_{3}{ }^{-}$was lower in the $\mathrm{pH} 5$ plots than in the other treatment plots, especially prior to $21 \mathrm{~d}$ after pig slurry application (Figure 1C). The lower rates of $\mathrm{NO}_{3}^{-}$leaching from soils amended with acidified slurry for this earlier period may be due to the priming effect of acidification on delaying nitrification, as shown by the higher levels of $\mathrm{NH}_{4}{ }^{+}$and lower soil $\mathrm{NO}_{3}{ }^{-}$content (Table 4). Cumulative $\mathrm{NO}_{3}^{-}$leaching declined throughout the experimental period, by $17.8 \%$ in the $\mathrm{pH} 5$ plots and by $9.6 \%$ in the $\mathrm{pH} 7$ plots, compared to the controls (Figure 2C). Thus, we conclude that only a small proportion of the total amount of $\mathrm{N}$ is lost via $\mathrm{NO}_{3}{ }^{-}$ leaching following application of acidified pig slurry. However, the apparent effects of pig slurry acidification on the overall environmental impact have significance.

\section{IMPLICATIONS}

Appropriate acidification of animal slurry represents an efficient means of improving the use efficiency of pig slurry- $\mathrm{N}$ with significant reductions in $\mathrm{NH}_{3}$ and $\mathrm{N}_{2} \mathrm{O}$ emission, as well as in $\mathrm{NO}_{3}{ }^{-}$leaching. The acid in the present study was added just before application of slurry in the field; however the slurry is often stored for a variable time before or after acidification. The stored time may influence the turnover of manure organic matter during storage and thereby also the $\mathrm{N}$ availability. Further studies would be useful to determine the mineralization dynamics and $\mathrm{N}$ loss of ammonia volatilization in relation to the storage time after acidification.

\section{CONFLICT OF INTEREST}

We certify that there is no conflict of interest with any financial organization regarding the material discussed in the manuscript.

\section{ACKNOWLEDGMENTS}

This study was carried out with the support of "Investigation for the use efficiency of different organic manures in upland grassland (Project No. PJ010099)" Rural Development Administration, Republic of Korea.

\section{REFERENCES}

1. Ministry of Agriculture, Food and Rural Affairs. Outcome of animal waste generation and recycling (2006-2012). Sejong, Korea: Ministry of Agriculture, Food and Rural Affairs; 2013.

2. Schröder J. Revisiting the agronomic benefits of manure: a correct assessment and exploitation of its fertilizer values spares the environment. Bioresour Technol 2005;96:253-61.

3. Fanguerio D, Maibritt H, Gioelli F. Acidification of animal slurry - a review. J Environ Manage 2015;149:46-56.

4. Bittman S, Mikkelsen R. Ammonia emissions from agricultural operations: livestock. Better Crops 2009;93:28-31.

5. Chantigny MH, Angers DA, Morvan T, Pomar C. Dynamics of pig slurry nitrogen in soil and plant as determined with ${ }^{15} \mathrm{~N}$. Soil Sci Soc Am J 2004;68:637-43. 
6. Hoekstra NJ, Lalor STJ, Richards KG, et al. Slurry ${ }^{15} \mathrm{NH}_{4}-\mathrm{N}$ recovery in herbage and soil: effects of application method and timing. Plant soil 2010;330:357-68.

7. EEA. Ammonia $\left(\mathrm{NH}_{3}\right)$ emissions (APE 003) [Internet]. Copenhagen, Denmark: 2014 [cited 2014 Jan 29]. Available from: http://www.eea.europa.eu/data-and-maps/indicators/eea-32ammonia-nh3-emissions-1/assessment-4

8. Eriksen J, Nørgaard JV, Poulsen HD, et al. Effects of acidifying pig diets on emissions of ammonia, methane, and sulfur from slurry during storage. J Environ Qual 2014;43:2086-95.

9. Balsari P, Dinuccio E, Gioelli F. A low cost solution for ammonia emissionabatement from slurry storage. Int Congr Ser 2006; 1293:323-6.

10. Webb J, Pain B, Bittman S, Morgan J. The impacts of manure application methods on emissions of ammonia, nitrous oxide and on crop response - a review. Agric Ecosyst Environ 2010; 137:39-46.

11.Gilsanz C, Bàez D, Misselbrook TH, Dhanoa MS, Càrdenas LM. Development of emission factors and efficiency of two nitrification inhibitors, DCD and DMPP. Agric Ecosyst Environ 2016;216:1-8.

12. Moeletsi ME, Tongwane MI. 2004 Methane and nitrous oxide emission from manure management in South Africa. Animals 2015;5:193-205.

13. Fangueiro D, Pereira J, Bichana A, et al. Effects of cattle-slurry treatment by acidification and separation on nitrogen dynamics and global warming potential after surface application to an acidic soil. J Environ Manage 2015;162:1-8.

14. Kai P, Pedersen P, Jensen JE, Hansen MN, Sommer SG. A whole-fram assessment of the efficacy of slurry acidification in reducing ammonia emission. Eur J Agron 2008;28:148-54.

15. Birkmose T, Vestergaard A. Acidification of slurry in barns, stores and during application: review of Danish research, trials and experience. In: Proceedings from the 15th RAMIRAN Conference; 2013 Jun 3-5: Versailles, France.

16.Petersen J, Lemming C, Rubæk GH. Side-band injection of acidified cattle slurry as starter P-fertilization for maize seedlings. In: Proceedings from the 15th RAMIRAN Conference; 2013 Jun 3-5: Versailles, France.

17.Gustafsson G, Jeppsson KH. Ammonia reduction from dairy houses. In: Geers R, Madec F, editors. Livestock production and society. The Netherlands: Wageningen Academic Publishers; 2006. p. 167-79.

18. Ourry A, Bourcaud J, Salette J. Partitioning and remobilization of nitrogen during regrowth of ryegrass subjected to nitrogen deficiency. Crop Sci 1990;30:1251-4.

19. Kim TH, Ourry A, Boucaud J, Lemaire G. Changes in sourcesink relationship for nitrogen during regrowth of Lucerne (Medicago sativa L.) following removal of shoots. Aust J Plant Physiol 1991;18:593-602.

20.Ndegwa PM, Vaddella VK, Hristov AN, Joo HS. Measuring concentration of ammonia in ambient air or exhaust air steam using acid traps. J Environ Qual 2009;38:647-53.

21. Kim TH, Kim BH. Ammonia microdiffusion and colorimetric method for determining nitrogen in plant tissues. J Korean Soc Grassl Sci 1996;16:253-9.

22. Guo Y, Li B, Di H, Zhang L, Gao Z. Effects of dicyandiamide (DCD) on nitrate leaching, gaseous emissions of ammonia and nitrous oxide in a greenhouse vegetable production system in northern China. Soil Sci Plant Nutr 2012;58:647-58.

23. Kelly H, Annemie R, Hauke S, Dirk S, Winnie D. Determinants of the microbial community structure of eutrophic, hyporheic river sediments polluted with chlorinated aliphatic hydrocarbons. FEMS Microbiol Ecol 2014;87:715-32.

24.SAS Institute. SAS User's Guide: Statistics (fourth ed.). Cary, NC, USA: SAS Institute; 1982.

25. Park SH, Lee BR, Cho WM, Kim TH. Comparative nitrogen use efficiency of urea and pig slurry for regrowth yield and nutritive value in perennial ryegrass sward. Asian-Australas J Anim Sci 2017;30:514-22.

26. Burger M, Jackson LE. Microbial immobilization of ammonium and nitrate in relation to ammonification and nitrification rates in organic and conventional cropping systems. Soil Biol Biochem 2003;35:29-36.

27.Choi WJ, Ro HM, Chang SX. Recovery of fertilizer-derived inorganic- ${ }^{15} \mathrm{~N}$ in a vegetable field soil as affected by application of an organic amendment. Plant Soil 2004;263:191-201.

28. Fangueiro D, Surgy S, Coutinho J, Vasconcelos E. Impact of cattle slurry acidification on carbon and nitrogen dynamics during storage and after soil incorporation. J Plant Nutr Soil Sci 2013;176:540-50.

29. Sørensen P, Eriksen J. Effect of slurry acidification with sulphuric acid combined with aeration on the turnover and plant availability of nitrogen. Agric Ecosyst Environ 2009;131:240-46.

30. Gandhapudi SK, Coyne MS, Angelo EMD, Matocha C. Potential nitrification in alum treated soil slurries amended with poultry manure. Biores Technol 2006;97:664-70.

31. Frost JP, Stevens RJ, Laughlin RJ. Effect of separation and acidification of cattle slurry on ammonia volatilization and on the efficiency of slurry nitrogen for herbage production. J Agric Sci 1990;115:49-56.

32. Xu X, Zhou L, Van Cleemput O, Wang Z. Fate of Urea- ${ }^{15} \mathrm{~N}$ in a soil-wheat system as influenced by urease inhibitor bydroquinone and nitrification inhibitor dicyandiamide. Plant Soil 2000;220:261-70.

33.Zaman M, Zaman S, Adhinarayanan C, et al. Effects of urease and nitrification inhibitors on the efficient use of urea for pastoral systems. Soil Sci Plant Nutr 2013;59:649-59.

34. Choi WJ, Jin SA, Lee SM, RO HM, Yoo SH. Corn uptake and microbial immobilization of ${ }^{15} \mathrm{~N}$-labeled urea-N in soil as affected by composted pig manure. Plant Soil 2001;235:1-9.

35. Fangueiro D, Ribeiro $\mathrm{H}$, Coutinho J, et al. Nitrogen mineralization and $\mathrm{CO}_{2}$ and $\mathrm{N}_{2} \mathrm{O}$ emissions in a sandy soil amended with original or acidified pig slurries or with the relative frac- 
tions. Biol Fertil Soil 2010;46:383-91.

36. Wang K, Huang D, Ying H, Luo H. Effects of acidification during storage on emissions of methane, ammonia, and hydrogen sulfide from digested pig slurry. Biosyst Eng 2014;122: 23-30.

37. Erisman JW, Schaap M. The need for ammonia abatement with respect to secondary PM reductions in Europe. Environ Pollut 2004;129:159-63.

38. Dai X, Karring H. A determination and comparison of urease activity in feces and fresh manure from pig and cattle in relation to ammonia production and $\mathrm{pH}$ changes. PLoS One 2014;9: e110402.

39. Petersen SO, Andersen AJ, Eriksen J. Effects of cattle slurry acidification on ammonia and methane evolution during storage. J Environ Qual 2012;41:88-94.

40. Stevens RJ, Laughlin RJ, Frost JP. Effect of acidification with sulphuric acid on the volatilization of ammonia from cow and pig slurries. J Agric Sci 1989;113:389-95.

41. Nyord T, Liu D, Eriksen J, Adamsen APS. Effect of acidifcation and soil injection of animal slurry on ammonia and odour emission In: Proceedings from the 15th RAMIRAN Conference; 2013 Jun 3-5: Versailles, France.
42. Bussink DW, Huijsmans JFM, Ketelaars JJMH. Ammonia volatilization from nitric-acid-treated cattle slurry. Neth J Agric Sci 1994;42:4.

43. Pain BF, Misselbrook TH, Rees YJ. Effects of nitrificaiton inhibitor and acid addition to cattle slurry on nitrogen losses and herbage. Grass Forage Sci 1994;49:209-15.

44. Velthof G, Oenema O. Nitrous oxide from nitric-acid-treated cattle slurry applied to grassland under semi-controlled conditions. Neth J Agric Sci 1993;41:81-93.

45. Berg W, Türk M, Hellebrand HJ. Effects of acidifying liquid cattle manure with nitric or lactic acid on gaseous emissions. Workshop on Agricultureal Air Quality. Washington D.C USA: State of the Science, Department of Communication Service, North Carolina State University, Potomac, Maryland, USA; 2006. p. 492-8.

46. Morvan T, Leterme P, Arsène GG, Mary B. Nitrogen transformations after the spreading of pig slurry on bare soil and ryegrass using ${ }^{15} \mathrm{~N}$-labelled ammonium. Eur J Agron 1997;7: 181-8.

47. Cookson WR, Rowarth JS, Cameron KC. The effect of autumn applied ${ }^{15} \mathrm{~N}$-labelled fertilizer on nitrate leaching in a cultivated soil during winter. Nutr Cycl Agroecosyst 2000;56:99-107. 